This item was submitted to Loughborough's Research Repository by the author.

Items in Figshare are protected by copyright, with all rights reserved, unless otherwise indicated.

\title{
The effects of the elective or required status of courses on student
}

\section{evaluations}

PLEASE CITE THE PUBLISHED VERSION

PUBLISHER

(c) Taylor \& Francis

LICENCE

CC BY-NC-ND 4.0

REPOSITORY RECORD

Darby, Jenny A.. 2019. "The Effects of the Elective or Required Status of Courses on Student Evaluations". figshare. https://hdl.handle.net/2134/2627. 
This item was submitted to Loughborough's Institutional Repository by the author and is made available under the following Creative Commons Licence conditions.

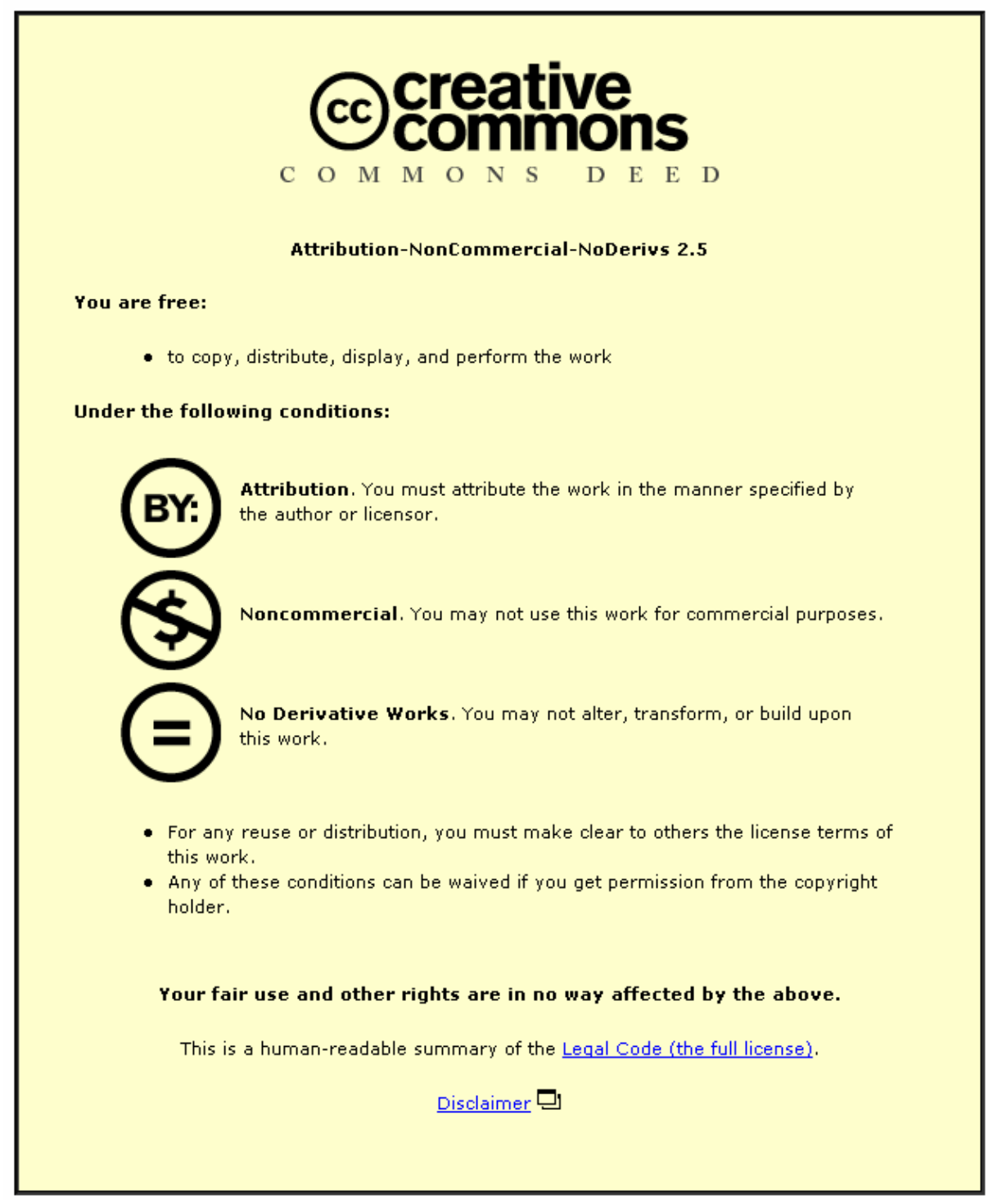

For the full text of this licence, please go to: http://creativecommons.org/licenses/by-nc-nd/2.5/ 


\title{
THE EFFECTS OF THE ELECTIVE OR REQUIRED STATUS OF COURSES ON STUDENT EVALUATIONS
}

\author{
Jenny A. Darby \\ Department of Social Sciences, Loughborough University, \\ Loughborough, Leicestershire. LE11 3TU \\ Email J.A.Darby@lboro.ac.uk
}

\begin{abstract}
This study examined the impact on a course evaluation of the course being either an elective or a required part of a training programme. Three elective and three required courses were evaluated using both a scaled and an open ended response form. Many variables were taken into account when examining the effect of course status, which other researchers have tended to neglect. These included the type of training method employed, the presenter and the type of student. It was found using a scaled response form that the elective courses received more favourable responses than the required courses on all three measures used, while on the open ended response forms, this occurred for two of the measures. It is suggested that, when comparing course evaluations, care should be taken to ensure that the status of the course as elective or required is taken into account.
\end{abstract}

\section{Introduction}

The literature into course evaluations using students is typified by that of Maynard et al (2002), who looked at how well psychology students remembered course material. From this they deduced that some presentations were better than others. Bradley et al (2005), emphasised the need to base evaluations on educational processes including course aims, objectives and outcomes. The study of factors which influence student perceptions of a course is an important area of research because of the trend towards the use of student evaluations in schools by OFSTED inspectors, and in colleges and universities as part of their external grading process. In many institutions such evaluations are mandated for all courses and are a subject for discussions with staff during performance appraisals. There is a growing tendency to include the evaluation of support units such as the media services and computing services departments on the basis of student ratings. In the United States many lecturers are actually paid on the basis of their student ratings. These evaluations are further used for comparisons between institutions and often form part of the calculations used for ranking them. The significance of those ratings will be very much less if the greater part of any difference is a result of the type of course content or other variables rather than the actual delivery.

Much previous research has failed to take into account a variable noticed by the present author and a small number of other researchers as being one which influences students' views of courses. This is whether the course is elective or required. Boland, Llehman \& Stroade (2001) point out, with most disciplines, that whether a course is an elective or a required one is a variable which relates to student attitudes towards educational programmes. Only a small number of studies, however, reported in electronic data basis and books on teacher training look at this area, but the findings are fairly consistent over time. An early study by Lovell \& Haner (1955) found teachers of elective courses generally received higher student ratings for their performance in evaluations than did those of required courses. In a subsequent study by Gage (1961) this was also found to be the case, although the study only used a series of Likert style rating scales. In another study, Pohlmann (1975), evaluated five aspects of courses, namely an overall view of how good the course was, how interested the tutor was in each student, how difficult the student found the course, whether assignments were clearly marked and how good the tutors actual presentation was. Pohlmann found that, employing these factors undergraduate students' evaluations on the elective courses were better on all measures than for the required courses. Looking at another aspect of type of course, Bassin (1974) reported instructors of quantitative courses received lower ratings than those of non-quantitative courses. Bassin's study used a rather narrow evaluation style including only Likert scales but was concerned with five aspects of the teaching: lecture quality, exam quality, text suitability, participation and consideration. More recently studies (eg. Drago \& Wagner 2004) have tended to neglect type of course and concentrate on aspects such as the relationship between effective teaching and the preferred learning style of the student. In the present study the evaluations provided by students taking part in elective and required courses were compared.

There are a number of methodological weaknesses with these studies concerned with type of course which the present author will address in the study to be reported in this article. First as McGoldrick \& Schuhmann (2002) point out, with electives, one of the factors students take into account when selecting the course is who the presenter is. It could well be a process of self-selection which influences the evaluations. Students only attend courses run by tutors they like, and therefore evaluations are likely to be good. Previous studies conducted with undergraduate evaluations have different instructors for each course so the type of course and the instructor both vary. The type of student attending various courses may also be different. Collins (1996) in a study of 483 students found those from different faculties, varied intellectually. In this instance, liberal arts and business studies students were compared. The liberal arts students were found to be more intellectually motivated. These three variables - the tutor, the course content and the type of student, raise the question as to the basis of the differences in the evaluation found by these researchers. They could have been a result of the elective/required nature of the courses or of differences between tutors, or the course content, or the students taking those courses, or a combination of all three? 
This present study examines the elective versus the required variable, which has been highlighted here. The participants taking the different courses were from the same population group of lecturers taking part in their probationary training programme. This took into account Collins's (1996) finding about academic disciplines, as these participants were distributed widely and fairly randomly across academic disciplines.

The present study uses both Likert style rating scales and open ended style questions as evaluation techniques. This takes the issues examined in this study far further than in that by Lovell \& Haner (1955) and other researchers who only looked at rating scales. It also looks at a wider range of items than did Pohlmann (1975) who concentrated solely on the presenter and did not take other aspects of courses into account

Some of the observations made about the variables present in the above research had a direct bearing on the selection of suitable training programmes for use in the present research project. Karen Chan (2001), found, nearly all evaluation studies measured the impact of teachers, but not student centred, or active learning approaches. The author felt it was necessary when looking at evaluations to ensure the three variables: the presenter, the type of teaching and the type of student were similar for all courses. In addition, in view of Bassin's (1974) finding about the poor evaluations given to quantitative courses, these were excluded. It was hoped that only the content of the courses and whether they were elective or required would differ. These requirements made the pool of courses from which to select limited.

It was hypothesised that:

1. On Likert scales students in elective courses would rate their courses more favourably than would those in required courses.

2. On open ended evaluation forms students in elective courses would make more favourable comments on their courses than would those in required courses.

\section{METHOD}

\section{Participants}

Data were gathered from the course evaluations of 185 probationary lecturers from seven East Midlands universities, who attended staff training courses. They were from a range of subject areas including business studies, engineering, science, social science and mathematics. This takes into account Collins's (1996) observation that students from different subject areas differ in various ways. This means that any differences found in the study are unlikely to be a result of the participants being from any particular academic discipline, as the sample is a cross section with approximately twenty percent coming from each of the above disciplines.

\section{Type of courses}

The major difference between courses, besides their actual content was that, for the required courses 93 lecturers were required to take them as part of their probationary training programme. The three topics of the required courses, all of which related to teaching skills, included: assessment; encouraging critical thinking and small groupwork, The other 92 lecturers attended elective courses provided by the same training department. These were part of a programme of 17 courses taught by 11 lecturers (which includes the lecturer in this study), intended to enhance individual development. The three topics of the elective courses were related to personal development and not directly to their employment. These included financial management, individual bargaining skills and managing occupational stress. Each course was conducted for at least two intakes of students with an average class size of about eleven. A total of seven intakes were included for both the elective and the required courses. The difference in the nature of the content meant that the courses were different not only in the fact they were elective or required but also in terms of type of content. Any differences found therefore could be a result of the matter of choice or of the type of content. This needs to be taken into account, although for convenience the tables of results will refer to elected and required courses.

A single male tutor taught all six courses included in the study. This was important in the light of the comment by McGoldrick \& Schuhmann (2002), that a factor students take into account when selecting an elective is who the presenter is. The presenter had taught each course on at least six occasions, and in an informal interview with the researcher claimed to feel equally competent with each and to have no marked preferences. The researcher, herself and experienced lecturer, observed the presenter teaching each of the elective and required courses (none of these sessions were included in the data collection for the present study) and found no noticeable difference in performance. There was therefore reason to believe with the same presenter teaching on both elective and required courses the characteristics of the presenter was not a factor likely to influence the results. It did have the effect, however, of severely restricting the number of courses which could be included in the study. Another restriction on the availability of data was that to be included, a course had to be taught using the same tuition methods. The half day 'workshop' approach was used which consisted of a combination of lecture, group discussion and participatory exercises.

\section{Evaluation forms}

All the evaluation forms used were the same for each course and used a format, which included both rating scales and open ended sections. The rating scales included scales concerning a wide range of factors, as discussed below. 


\section{Categorisation of evaluation responses}

This involved allocating each question on the Likert scales and every statement made on each open ended evaluation form to a category. This was done thematically based partly on a review of related literature. The factors were identified from a number of sources. Parrot, Sabini \& Silver (1988), for example, stressed how people, whatever they really feel, tend to react favourably to persons and express their unfavourable feelings towards inanimate objects. Morgan, Carder \& Neal (1997) stressed the importance of groups and how people turn to them for support. Most course evaluations are concerned with the presenter/tutor/lecturer. This and related aspects of a course are referred to subsequently in this paper as 'human related factors'. Further factors were derived from Herzberg (1966), who referred to feelings of achievement and satisfaction, which people express when they are feeling positive about their work. These factors are referred to as 'feelings about content'. Herzberg (1966) and Wall (1973) highlighted the use of 'hygiene factors' when wanting to express displeasure. In the present study, inanimate or physical aspects of the environment such as room temperature, comfort of chairs, refreshments, administrative factors such as joining instructions, visual aids and library resources were categorised as 'hygiene factors'.

\section{RESULTS}

Hypothesis 1. On Likert scales students in elective courses would rate their courses more favourably than would those in required courses.

This hypothesis is supported for as can be seen in table I the scores for the evaluations are higher for the elective than for the required courses. This applies for all three factors.

Table I

Showing comparisons between elective and required courses on the structured section of the evaluation forms

\begin{tabular}{|c|c|c|c|c|}
\hline $\begin{array}{l}\text { Individual statements grouped } \\
\text { in categories }\end{array}$ & $\begin{array}{l}\text { Mean scores } \\
\text { Reqd } \mathrm{N}=93 \\
\text { Elec. } \mathrm{N}=92\end{array}$ & $\begin{array}{l}\text { Standard } \\
\text { deviation }\end{array}$ & $\begin{array}{l}\text { t. score } \\
\text { df. }=183\end{array}$ & Significance \\
\hline \multicolumn{5}{|l|}{ Human Related statements } \\
\hline $\begin{array}{ll}\text { Quality of } & \text { Req } \\
\text { Presentation } & \text { Elec }\end{array}$ & $\begin{array}{l}4.04 \\
4.52 \\
\end{array}$ & $\begin{array}{l}0.81 \\
0.58\end{array}$ & 4.62 & $.000 *$ \\
\hline $\begin{array}{ll}\text { Quality of } & \text { Req } \\
\text { Group mang } & \text { Elec }\end{array}$ & $\begin{array}{l}3.96 \\
4.08\end{array}$ & $\begin{array}{l}1.11 \\
0.94\end{array}$ & 0.79 & .433 \\
\hline $\begin{array}{ll}\text { Appropriate } & \text { Req } \\
\text {-ness of level } & \text { Elec }\end{array}$ & $\begin{array}{l}3.95 \\
4.30 \\
\end{array}$ & $\begin{array}{l}0.99 \\
0.68 \\
\end{array}$ & 2.87 & $.005^{*}$ \\
\hline $\begin{array}{lr}\begin{array}{l}\text { Integration } \\
\text { of parts }\end{array} & \text { Req } \\
\text { Elec }\end{array}$ & $\begin{array}{l}3.85 \\
4.12 \\
\end{array}$ & $\begin{array}{l}1.13 \\
0.77 \\
\end{array}$ & 1.90 & .06 \\
\hline $\begin{array}{l}\text { Total human Req } \\
\text { Related Elec }\end{array}$ & $\begin{array}{l}15.80 \\
17.02 \\
\end{array}$ & $\begin{array}{l}3.09 \\
2.02 \\
\end{array}$ & 3.19 & $.002 *$ \\
\hline \multicolumn{5}{|c|}{ Feelings about content statem } \\
\hline $\begin{array}{ll}\text { Enjoyability } & \text { Req } \\
\text { of course } & \text { Elec }\end{array}$ & $\begin{array}{l}4.11 \\
4.61\end{array}$ & $\begin{array}{l}0.80 \\
0.51\end{array}$ & 5.07 & $.000^{*}$ \\
\hline $\begin{array}{ll}\text { Meet needs } & \text { Req } \\
& \text { Elec } \\
\end{array}$ & $\begin{array}{l}4.19 \\
4.47 \\
\end{array}$ & $\begin{array}{l}0.74 \\
0.64 \\
\end{array}$ & 2.69 & $.008 *$ \\
\hline $\begin{array}{ll}\text { Useful } & \text { Req } \\
& \text { Elec } \\
\end{array}$ & $\begin{array}{l}4.16 \\
4.46 \\
\end{array}$ & $\begin{array}{l}1.02 \\
0.56\end{array}$ & 2.43 & $.016 *$ \\
\hline $\begin{array}{ll}\text { Total Feelings } & \text { Req } \\
\text { Content } & \text { Elec } \\
\end{array}$ & $\begin{array}{l}12.46 \\
13.53 \\
\end{array}$ & $\begin{array}{l}2.16 \\
1.30\end{array}$ & 4.07 & $.000 *$ \\
\hline \multicolumn{5}{|l|}{ Hygiene statements } \\
\hline $\begin{array}{ll}\text { Consistency } & \text { Req } \\
\text { Publicity } & \text { Elec }\end{array}$ & $\begin{array}{l}3.92 \\
4.33\end{array}$ & $\begin{array}{l}1.02 \\
0.80\end{array}$ & 2.97 & $.003 *$ \\
\hline $\begin{array}{ll}\text { Quality of } & \text { Req } \\
\text { Audio-visual } & \text { Elec }\end{array}$ & $\begin{array}{l}3.23 \\
3.97 \\
\end{array}$ & $\begin{array}{l}1.45 \\
0.86\end{array}$ & 4.22 & $.000 *$ \\
\hline $\begin{array}{ll}\text { Quality of } & \text { Req } \\
\text { Handouts } & \text { Elec }\end{array}$ & $\begin{array}{l}4.08 \\
4.32\end{array}$ & $\begin{array}{l}0.80 \\
0.69\end{array}$ & 2.18 & $.030 *$ \\
\hline $\begin{array}{r}\text { Administration Req } \\
\text { Elec }\end{array}$ & $\begin{array}{l}3.90 \\
4.27 \\
\end{array}$ & $\begin{array}{l}1.22 \\
0.61 \\
\end{array}$ & 2.67 & $.008 *$ \\
\hline $\begin{array}{ll}\text { Good equal } & \text { Req } \\
\text { Opportunities } & \text { Elec }\end{array}$ & $\begin{array}{l}3.46 \\
3.95\end{array}$ & $\begin{array}{l}1.72 \\
1.16\end{array}$ & 2.24 & $.027 *$ \\
\hline $\begin{array}{ll}\text { Total } & \text { Req } \\
\text { Hygiene } & \text { Elec } \\
\end{array}$ & $\begin{array}{l}18.58 \\
20.74 \\
\end{array}$ & $\begin{array}{l}3.60 \\
2.57 \\
\end{array}$ & 4.69 & $.000^{*}$ \\
\hline $\begin{array}{l}\text { Req } \\
\text { Elec }\end{array}$ & $\begin{array}{l}3.30 \\
4.38\end{array}$ & $\begin{array}{l}1.78 \\
0.85\end{array}$ & 5.25 & $.000^{*}$ \\
\hline
\end{tabular}

Hypothesis 2. On open ended evaluation forms students in elective courses would make more favourable comments on their courses than would those in required courses. 
Support for this hypothesis is limited for, as can be seen in table II, with the favourable open ended evaluation scores there is a significant difference on only two of the three factors. In the table the mean number of statements represent those made by the total sample of 93 for the required and 92 for the elective groups. The 'content' and 'hygiene factors' are regarded more favourably for the elective courses than they are for the required courses. For the 'human related factors' there is no significant difference. Maybe the control of having the same lecturer throughout worked! The interesting point here is that the qualitative responses were subjected to a statistical interpretation. This is not the usual manner in which this sort of data is treated. Normally the comments would be reviewed and considered individually or possibly used as clarification of more structured scales. Here the two parts of the evaluation are considered separately, for often evaluations consist of one or other technique not both. Qualitative evaluations have been considered here in numeric terms in order that the weighting or balance of comments can be compared between the two types of courses. The frequency of qualitative statements does have an impact on the significance of interpretations made. For the limited purposes of this study the concern is with the balance of comments, whether they were favourable or unfavourable, rather more than their individual content and intensity.

Table II

Showing number of favourable responses on the open ended section of the evaluation questionnaire.

\begin{tabular}{|l|l|l|l|l|}
\hline Statement category & $\begin{array}{l}\text { Mean scores } \\
\text { Reqd. N=93 } \\
\text { Elec. N=92 }\end{array}$ & $\begin{array}{l}\text { Standard } \\
\text { deviation }\end{array}$ & $\begin{array}{l}\text { t. score } \\
\text { df. = 183 }\end{array}$ & Significance \\
\hline $\begin{array}{l}\text { Total favourable human related } \\
\text { score }\end{array}$ & 1.99 & & & \\
Req'd & 1.57 & 2.51 & 1.18 & .238 \\
Elec & & 2.36 & & \\
\hline $\begin{array}{l}\text { Total feelings about } \\
\text { Content score }\end{array}$ & 0.63 & 1.58 & 6.46 & $\mathbf{. 0 0 0 *}$ \\
Req'd & 2.63 & 2.52 & & \\
Elec & & & & \\
\hline Total favourable hygiene score & & 1.17 & 2.43 & $\mathbf{. 0 1 6 *}$ \\
Req'd & 0.44 & 0.60 & & \\
Elec & 0.11 & &
\end{tabular}

As can be seen in table III there was no difference in unfavourable comments for any of the three open ended categories between required or elective courses.

Table III

Showing the number of unfavourable responses on the open ended section of the evaluation questionnaire.

\begin{tabular}{|l|l|l|l|l|}
\hline Statement category & $\begin{array}{l}\text { Mean scores } \\
\text { Reqd. N=93 } \\
\text { Elec. N=92 }\end{array}$ & $\begin{array}{l}\text { Standard } \\
\text { deviation }\end{array}$ & $\begin{array}{l}\text { t. score } \\
\text { df. = 183 }\end{array}$ & Significance \\
\hline $\begin{array}{l}\text { Total unfavourable responses fo } \\
\text { human related score. }\end{array}$ & & & & \\
$\begin{array}{l}\text { Req'd } \\
\text { Elec }\end{array}$ & 0.33 & 1.10 & 0.296 & .768 \\
& 0.28 & 1.23 & & \\
\hline $\begin{array}{l}\text { Total unfavourable feelings abo } \\
\text { content score }\end{array}$ & & & & \\
$\begin{array}{l}\text { Req'd } \\
\text { Elec }\end{array}$ & 0.16 & 0.77 & 0.452 & .652 \\
\hline $\begin{array}{l}\text { Total unfavourable } \\
\text { score }\end{array}$ & 0.22 & 0.91 & & \\
$\begin{array}{l}\text { Req'd } \\
\text { Elec }\end{array}$ & 0.55 & & & \\
\hline
\end{tabular}

\section{DISCUSSION}

This study has made a contribution to our understanding of the effect of the type of course on evaluations. Previous studies (eg Polhmann, 1975) have included large samples with many courses, but with few controls. Lecturers differed from course to course, the content of courses varied and the students differed. The results of the Likert scale ratings used in this study were predicted on the basis of previous research findings (Pohlmann, 1975). The three aspects of the course including 'human related factors', 'feelings about course content' and 'hygiene factors' were all regarded more 
favourably by students on the elective course than by those on the required course. In the previous studies different presenters were used for different courses. With the present study a single presenter was used for both types of course. The result on the Likert scale means either the presenter performed better for the elective courses or the students favourable view of him was determined rather more by whether they had elected to do the course or not. It is understandable that the content would be more appealing to students if a course was an elective rather than a required one. They had chosen to do it. It really is hard to see why the presenter should perform any better. To the lecturer they are not elective or required courses, he is simply expected to teach both and uses the same workshop approach for both the elective and the required courses. It is just as difficult to see why the 'hygiene factors' should be regarded better. The same administrative team was running both types of courses and there is again no reason why they should treat one differently from another. For them the job is the same whether the students is taking the course as an elective or a required course. In the same way visual aids, library resources, catering arrangements were all similar for the elective and the required courses. It would certainly seem as though the more favourable rating of the elective course, is a result of the reaction of the student to choosing the course rather than the 'hygiene factors' being better.

At this point it is important to acknowledge a weakness of the study, for although the two types of course differ in terms of whether they are compulsory their content also differs. The required courses are all to do with teaching skills. The elective courses are all to do with personal development. It could be suggested this is the cause of the difference rather than whether they are an elective or required. This criticism is justified. Sadly there are few examples of courses attended by some students as an elective and by others as a required subject. The researcher found that where this did occur those attending as a required element were students specialising in the subject and those attending as an elective were from another subject discipline. A strength of the present research design is that the three elective courses included in the present study differed from each other quite markedly in content and so did the three required courses. It is likely, therefore, that some would be intrinsically of greater interest to individual students than others. The elective variable it is argued here was an important factor in accounting for the consistent differences between the two groups of courses. The results of the study are important as more variables have been controlled than in any previous study. It shows students prefer elective rather than required courses which is an important finding when all the variables previous researchers have failed to control have been taken into account.

Previous studies are also limited in the type of evaluation they use. They are usually concerned solely with rating scales. The open ended evaluations reported in this study produce different results from the Likert scales and suggests the two formats are producing different reactions from the students. The open ended comments produce significantly more favourable responses for the 'content' and ''hygiene scores' for the elective rather than the required courses. Again it is easy to understand the difference for the 'content' element as the courses were chosen on the basis of what they were about, but less easy to account for the difference for the 'hygiene element'. It is noticeable that the 'human related element' produces no such difference. With the unfavourable open ended statements there were no significant differences between the reports of those attending the elective or required courses.

The results of this study support the findings of previous research which showed that the nature of an evaluation students give to a course is influenced by whether they have chosen to take that course or not. It shows, by using different evaluation forms, namely Likert style or open ended, how this pattern of results varies. It does go further than the previous research for it indicates these differences are much more widespread than was previously thought. As well as affecting the view of the content of the course, as would be expected, it also affects the view of the lecturer and even the administration involved with that course.

This result is important for those involved with teaching modules. This study has provided some evidence to support the view that some elements of evaluation are decided by factors which have nothing to do with the quality of teaching on the course. In this present study, whether a course was an elective or required has been shown to influence how well regarded it was by the students. In a similar way Bassin (1974) showed whether a course was quantitative determined how favourable students were to it. This is where sponsoring bodies like a School, College, Local Education Authority or University need to be involved. They should be urged to build up a data bank from other courses conducted under their remit. This could be used to provide a yardstick against which to compare the evaluation outcomes of any individual course. Required courses should be compared with other required courses and not with courses taken as electives. Like should be compared with like. This study provides some evidence to suggest crude evaluations where different types of courses are simply compared to each other are totally inadequate.

\section{Acknowledgement:}

This empirical study is integrated in the author's own doctoral thesis.

\section{REFERENCES}

Bassin, W. M. (1974) A note on the biases in students' evaluations of instructors'. Journal of Experimental Education 43. 16-17

Boland, M. Lehman, E. \& Stroade, J. (2001) A comparison of curriculum baccalaureate degree programs in agribusiness. The International food and agribusiness management review. 225-235

Bradley, P. Nordheim, L. De La Harpe, D. Innvaer, S. \& Thompson, C. (2005). A systematic review of qualitative literature on educational interventions for evidence-based practice. Learning in Health and Social Care. 4. 2. 89-109. 
Chan, K. (2001) The difficulties and dilemma of constructing a model for teacher evaluation in higher education. Higher Education Management. 13.1. 93-111

Collins, J.W. (1996) Intellectual motivation and its relationship to selected characteristics of collegiate business and liberal arts majors. Dissertation Abstracts International. Section A. Humanities and Social Sciences. 56. (10-A) 3886.

Drago, W.A. \& Wagner, R.J. (2004) Vark preferred learning styles and online education. Management Research News, 27.7. 1-13.

Herzberg, F. (1966). Work and the Nature of Man. Cleveland. World Publishing.

Lovell, G.D. \& Haner, C.F. (1955) Forced choice applied to college faculty rating. Educational and Psychological Measurement. 15. 291-304

Maynard, D.C., Bachiochi, P.D. \& Luna, A.C. (2002) An evaluation of industrial/organizational psychology teaching modules for use in introductory psychology. Teaching of Psychology 29.1.39-43

McGoldrick, K \& Schuhmann, P.W. (2002) Instructor gender and student registration: An analysis of preferences. Education Economics. 10.3. 241-260

Morgan, D. Carder, P. \& Neal, M. (1997) Are some relationships more useful than others? The value of similar others in the networks of recent widows. Journal of Social and Personal Relationships. 14. 745-759

Parrot, W.G., Sabini, J. \& Silver, M. (1988) The roles of self-esteem and social interaction in embarrassment. Personality and Social Psychology Bulletin. 14. 191-202

Pohlmann, J.T. (1975) A multivariate analysis of selected class characteristics and student ratings of instructions. Multivariate Behavioural Research. 10.1. 81-91

Wall, T.D. (1973) Ego-defensiveness as a determinant of reported differences in sources of job satisfaction and job dissatisfaction. Journal of Applied Psychology. Aug. 58.(1) 125-128

\section{Biographical note:}

Jenny Darby has a varied career in Education. She taught in an inner city Comprehensive school for 25 years completing her service as Head of Science. For two years during a secondment she was responsible for a county wide training programme for head teachers and senior teaching staff. She has recently been running training workshops in teaching skills for postgraduates at Loughborough University, where she completed her doctorate. Her main research interest concerns evaluation of training programmes. E mail J.A.Darby@lboro.ac.uk 